\title{
Kompetensi Pedagogik Guru dalam Melaksanakan Pembelajaran Tematik di Madrasah Ibtidaiyah Miftahul Hidayah Tegalsari Banyuwangi
}

\author{
Ulfi Khoirotul Ummah \\ Universitas Jember \\ ulfikhoirummah@gmail.com \\ Akhmad Munir \\ Universitas Jember \\ akhmadmunir@yahoo.com
}

\begin{abstract}
Abstrak
Kompetensi pedagogik merupakan kemampuan yang harus dimiliki guru dalam mengelola pembelajaran. Berkaitan dengan pengelolaan Pembelajaran Tematik fakta di sekolah menunjukkan banyak guru belum sepenuhnya mampu mengimplementasikan pembelajaran yang memiliki prinsip mengintegrasikan banyak materi. Untuk itu, penelitian ini bertujuan untuk mendeskripsikan kemampuan guru: 1) Memahami peserta didik dalam melaksanakan Pembelajaran Tematik di MI Miftahul Hidayah Tegalsari Tahun Pelajaran 2018/2019. 2) Merencanakan pembelajaran dalam melaksanakan Pembelajaran Tematik di MI Miftahul Hidayah Tegalsari Tahun Pelajaran 2018/2019. 3) Melaksanakan pembelajaran pada Pembelajaran Tematik di MI Miftahul Hidayah Tegalsari Tahun Pelajaran 2018/2019. 4) Mengevaluasi hasil belajar dalam melaksanakan Pembelajaran Tematik di MI Miftahul Hidayah Tegalsari Tahun Pelajaran 2018/2019. Hasil penelitian menunjukkan bahwa: 1) Kemampuan guru memahami peserta didik sudah sesuai indikator kompetensi pedagogik. 2) Kemampuan guru merencanakan pembelajaran sudah sesuai dengan indikator kompetensi pedagogik. 3) Kemampuan guru dalam melaksanakan pembelajaran ada satu indikator yang perlu diperbaiki. 4) Kemampuan dalam mengevaluasi hasil belajar sudah sesuai dengan indikator kompetensi pedagogik.
\end{abstract}

Kata Kunci: Kompetensi Pedagogik; Pembelajaran Tematik 


\section{PENDAHULUAN}

Pada dasarnya Pembelajaran Tematik merupakan basis pembelajaran pada kurikulum 2013 yang disebut pembelajaran berbasis terpadu. Model pembelajaran ini telah membawa perubahan yang mendasar terhadap peran guru dari model pembelajaran kurikulum sebelumnya. Dalam model ini, guru harus berperan secara aktif sebagai fasilitator dengan memberikan kemudahan belajar bagi seluruh peserta didik agar dapat mengembangkan potensinya secara optimal. Selain itu, penilaian pada pembelajaran ini meliputi tiga aspek yaitu penilaian sikap, pengetahuan, dan keterampilan. Berbeda halnya dengan kurikulum sebelumnya yang hanya menitikberatkan pada aspek kompetensi pengetahuan saja. Hal ini menjadi beban tersendiri kepada guru.

Berdasarkan hasil observasi di Madrasah Ibtidaiyah Miftahul Hidayah Tegalsari pada Pembelajaran Tematik, realita yang terjadi menunjukkan bahwa sebagian besar guru Pembelajaran Tematik belum maksimal dalam melaksanakan proses pembelajaran. ${ }^{1}$ Berkaitan dengan hal tersebut, salah satu kompetensi guru yang dianggap dapat membantu dalam permasalah tersebut adalah kompetensi pedagogik, karena kompetensi pedagogik berkaitan dengan proses pembelajaran yang dilakukan di dalam kelas.

Adapun yang dimaksud dengan kompetensi pedagogik guru dalam Standar Nasional Pendidikan, penjelasan Pasal 28 ayat (3) butir a dikemukakan bahwa kompetensi pedagogik adalah kemampuan mengelola pembelajaran peserta didik yang meliputi pemahaman terhadap peserta didik, perancangan dan pelaksanaan pembelajaran, evaluasi hasil belajar, dan pengembangan peserta didik untuk mengaktualisasikan berbagai potensi yang dimilikinya. ${ }^{2}$ Dengan demikian kompetensi pedagogik ini sangat penting untuk dikuasai oleh guru Pembelajaran Tematik. Hal ini sesuai

${ }^{1}$ Observasi, Banyuwangi, 06 Februari 2019.

2 E. Mulyasa, Standar Kompetensi dan Sertifikasi Guru (Bandung: PT Remaja Rosdakarya, 2012), 75. 
dengan pengertian Pembelajaran Tematik Terpadu yang dijelaskan oleh Rusman, bahwa:

Pembelajaran Tematik merupakan salah satu model dalam pembelajaran terpadu (integrated instruction) yang merupakan suatu sistem pembelajaran yang memungkinkan peserta didik, baik secara individual maupun kelompok, aktif menggali dan menemukan konsep serta prinsip-prinsip keilmuan secara holistik, bermakna, dan autentik. $^{3}$

Berdasarkan kutipan di atas, Pembelajaran Tematik memiliki tujuan tertentu pada setiap pembelajarannya, yakni berorientasi pada praktek pembelajaran yang sesuai dengan kebutuhan dan perkembangan peserta didik. Hal ini menunjukkan bahwa kompetensi pedagogik guru sangat penting dalam proses Pembelajaran Tematik. Oleh karena itu, sesuai dengan UU No. 14 tahun 2005 Bab IV Pasal 8 tentang Kualifikasi, Kompetensi, dan Sertifikasi menjelaskan bahwa setiap guru wajib memiliki kualifikasi akademik, kompetensi, sertifikat pendidik, sehat jasmani dan rohani, serta memiliki kemampuan untuk mewujudkan tujuan pendidikan nasional. ${ }^{4}$

Hal itu dikarenakan guru dalam proses belajar mengajar memiliki peran yang sangat berpengaruh pada keberhasilan para generasi bangsa. Guru menurut pandangan lama adalah sosok yang patut "digugu" dan "ditiru". "Digugu" dalam arti, segala ucapannya dapat dipercayai, "Ditiru" dalam arti, segala tingkah lakunya harus dapat menjadi contoh atau teladan bagi masyarakat. ${ }^{5}$ Berdasarkan pandangan tersebut, maka seorang guru harus memiliki kompetensi yang bagus karena memiliki peranan penting sebagai sumber utama untuk mengetahui atau mempelajari ilmu dan pengetahuan yang nantinya akan menjadi panutan sebagai bekal para peserta didiknya. Hal ini telah dijelaskan dalam UU RI No. 14 tahun 2005 bahwa:

\footnotetext{
${ }^{3}$ Rusman, Pembelajaran Tematik Terpadu Teori, Praktik dan Penilaian (Jakarta: PT Grafindo Persada, 2015), 254.

${ }^{4}$ Permendiknas, UU RI, 64.

${ }^{5}$ Ahmad Izzan et al, Membangun Guru Berkarakter (Bandung: Humaniora,tt), 31.
} 
Kompetensi guru adalah seperangkat pengetahuan, keterampilan, dan perilaku yang harus dimiliki, dihayati, dan dikuasai oleh guru atau dosen dalam melaksanakan tugas profesionalisme. Pada pasal 10 ayat 1 disebutkan kompetensi guru meliputi: 1) kompetensi pedagogik, 2) kompetensi kepribadian, 3) kompetensi sosial, dan 4) kompetensi profesional. ${ }^{6}$

Jadi, profesionalisme guru dalam melaksanakan tugas tergantung pada kemampuan yang dimiliki guru bersangkutan. Kemampuan yang dimaksud adalah kompetensi dari guru tersebut. Kompetensi yang dimiliki oleh setiap guru akan menunjukkan kualitas guru itu sendiri. Kompetensi tersebut akan terwujud dalam penguasaan pengetahuan, keterampilan, maupun profesional dalam menjalankan fungsi sebagai guru. Kompetensi yang dimaksud yaitu kompetensi pedagogik, kompetensi kepribadian, kompetensi sosial, dan kompetensi profesional.

Berdasarkan uraian di atas, untuk mengetahui faktor penentu keberhasilan Pembelajaran Tematik mengenai kesesuaian kompetensi pendidik khususnya kompetensi pedagogik guru maka perlu dilakukan analisis kesesuaian kompetensi pedagogik guru dalam pelaksanaan Pembelajaran Tematik. Oleh karena itu, peneliti mengadakan penelitian di MI Miftahul Hidayah Tegalsari dengan asumsi bahwa lembaga ini merupakan salah satu lembaga pendidikan swasta yang sudah berdiri sejak tahun 1953, juga sudah dapat diterima dan diakui oleh masyarakat. Dibuktikan dengan banyaknya peserta didik yang bersekolah di lembaga tersebut yakni berjumlah 242 anak. Hal ini menunjukkan bahwa banyaknya orangtua/masyarakat yang mempercayakan lembaga tersebut sebagai tempat menuntut ilmu bagi anaknya. Sebagaimana hasil wawancara dengan salah satu orangtua peserta didik mengatakan bahwa:

Karena menurut saya di sekolah ini jika dibandingkan dengan sekolah lainnya yang ada sekitar sini, yang memiliki prestasi cukup bagus ya di sekolah ini. Banyak siswa yang meraih prestasi ketika lomba-lomba

6 Permendiknas, UU RI No. 14 Tahun 2005 tentang Guru dan Dosen, (Jakarta: Transmedia Pustaka, 2008), 61. 
itu. Saat olimpiade juga mendapatkan juara. Jadi saya juga kepingin anak saya seperti itu jadi saya sekolahkan di sini. ${ }^{7}$

Sebagai lembaga pendidikan yang bertanggung jawab untuk melahirkan dan menjadikan peserta didiknya sebagai generasi penerus bangsa yang kompetitif, maka kompetensi guru dalam melaksanakan pembelajaran menjadi sangat penting. Pada penelitian ini difokuskan pada guru Pembelajaran Tematik di kelas tiga, sesuai asumsi waka kurikulum berdasarkan hasil wawancara bahwa guru tersebut merupakan guru yang dianggap paling kompetitif jika dibandingkan dengan guru Pembelajaran Tematik yang lainnya. Karena guru yang berkualitas adalah modal utama dalam mewujudkan proses pembelajaran yang baik. Oleh karena itu, peneliti ingin mengetahui sejauh mana tingkat kompetensi pedagogik guru pada tingkat sekolah dasar dengan judul "Kompetensi Pedagogik Guru dalam Melaksanakan Pembelajaran Tematik di Madrasah Ibtidaiyah Miftahul Hidayah Tegalsari Banyuwangi”.

\section{METODE PENELITIAN}

Peneliti ini menggunakan pendekatan kualitatif dengan jenis deskriptif. Subyek penelitian yang dijadikan informan ditentukan menggunakan purposive sampling. Purposive sampling adalah teknik pengambilan sampel sumber data dengan pertimbangan tertentu. ${ }^{8}$ Pertimbangan tertentu ini adalah orang yang akan dijadikan informan yaitu orang yang dapat memberikan informasi berupa data yang diperlukan oleh peneliti.

Berdasarkan uraian tersebut, yang dijadikan sebagai subyek penelitian ini adalah: (1) Kepala Madrasah (2) Guru Pembelajaran Tematik kelas III, dan (3) Peserta didik kelas III. Adapun teknik yang digunakan untuk

${ }^{7}$ Imanah, Wawancara, Banyuwangi, 06 Februari 2019.

8 Sugiyono, Metode Penelitian Kuantitatif Kualitatif dan R\&D (Bandung: Alfabeta, 2016), 216. 
mengumpulkan data dalam penelitian ini adalah teknik observasi, teknik wawancara dan teknik dokumentasi. Sedangkan analisis data dalam penelitian ini menggunakan analisis menurut Miles, Huberman, dan Saldana, yakni analisis data dalam penelitian kualitatif terdapat tiga alur aktivitas/kegiatan secara bersamaan. Aktivitas yang terjadi yaitu: kondensasi data, penyajian data, dan penarikan kesimpulan/verifikasi. ${ }^{9}$ Kondensasi data adalah proses pemilihan, pemfokusan, penyederhanaan, mengabstraksi, dan/atau mentransformasikan data dari catatan lapangan yang ditulis, transkrip wawancara, dokumen, dan bahan empiris lainnya. Penyajian data adalah sebuah pengorganisasian, penyatuan dan informasi yang memungkinkan penyimpulan dan tindakan. Kegiatan analisis yang ketiga adalah menarik kesimpulan dan verifikasi. Dari permulaan pengumpulan data, seorang penganalisis kualitatif mulai mencari arti benda-benda, mencatat keteraturan penjelasan, konfigurasi-konfigurasi yang mungkin, alur sebab akibat, proporsi, kesimpulan-kesimpulan "final” mungkin tidak muncul sampai pengumpulan data berakhir, tergantung besarnya kumpulankumpulan catatan lapangan, pengkodeannya, penyimpanan, dan metode pencarian ulang yang digunakan, kecakapan peneliti, dan tuntutan-tuntutan pemberian data. ${ }^{10}$

\section{HASIL TEMUAN}

Sesuai dengan Peraturan Pemerintah No. 19 Tahun 2005 tentang Standar Nasional Pendidikan pasal 28 ayat 3 butir a menyebutkan secara rinci kompetensi pedagogik mencakup lima indikator yang meliputi pemahaman terhadap peserta didik, perancangan dan pelaksanaan pembelajaran, evaluasi hasil belajar, dan pengembangan peserta didik untuk mengaktualisasikan berbagai potensi yang dimilikinya. Berdasarkan hasil

9 Miles, B. Mathew, A. Michael Huberman, dan Johny Saldana, Qualitative Data Analysis A Methods Sourcebook,(America: Arizona State Unversity, 2014), 14.

${ }^{10}$ Ibid., 10. 
penelitian yang dilakukan oleh peneliti dengan mengumpulkan data menggunakan teknik observasi, wawancara, dan dokumentasi mengenai kompetensi pedagogik guru dalam melaksanakan Pembelajaran Tematik di kelas III A dan III B Madrasah Ibtidaiyah Miftahul Hidayah Tegalsari Banyuwangi, dapat diuraikan sebagai berikut:

\section{Kemampuan Guru untuk Memahami Peserta Didik dalam Melaksanakan Pembelajaran Tematik}

Sesuai dengan hasil observasi, wawancara dan dokumentasi, peneliti dapat menyimpulkan bahwa guru pembelajaran Tematik kelas III A dan III B sudah melaksanakan pembelajaran sesuai dengan teori pemahaman peserta didik pada kompetensi pedagogik guru, yang mana pemahaman peserta didik ini mencakup pemahaman tingkat kecerdasan peserta didik, kreativitas, kondisi fisik, serta pertumbuhan dan perkembangan kognitif peserta didik.

a. Tingkat kecerdasan, kemampuan guru memahami ini yakni dengan cara melaksanakan pre-tes.

b. Kreativitas, kemampuan guru dalam memahami kreativitas peserta didik dengan cara mengajak peserta didik membuat kerajinan dalam praktek pembelajaran SBdP.

c. Kondisi fisik, kemampuan guru dalam memahami kondisi fisik dapat ditunjukkan dengan cara memberikan perlakuan yang berbeda.

d. Pertumbuhan dan perkembangan kognitif peserta didik, guru dapat mengetahuinya dengan cara mengamati selama proses pembelajaran setiap harinya.

Namun, hal itu belum bisa dijadikan tolok ukur keberhasilan dalam pembelajaran karena dalam proses pembelajaran untuk mencapai suatu keberhasilan harus memenuhi beberapa komponen yang menjadi ukuran keberhasilannya. 


\section{Kemampuan Guru Merencanakan Pembelajaran dalam Melaksanakan Pembelajaran Tematik}

Ukuran keberhasilan kompetensi Pedagogik yang kedua yaitu dari aspek perancangan pembelajaran. Perancangan merupakan kemampuan guru dalam mempersiapkan hal-hal sebelum melaksanakan kegiatan pembelajaran. Perancangan sama halnya dengan perencanaan. Perencanaan merupakan tahap awal dari suatu kegiatan yang bertujuan untuk mencapai suatu tujuan yang diinginkan. Kemampuan dalam merancang pembelajaran dapat diukur dengan kemampuan penyusunan program pembelajaran. Dalam hal ini guru sudah merencanakan dengan membuat RPP yang meliputi beberapa komponen di dalamnya.

\section{Kemampuan Guru dalam Melaksanakan Pembelajaran pada Pembelajaran Tematik}

Pembelajaran Tematik merupakan pembelajaran yang ditujukan untuk mengembangkan potensi peserta didik agar memiliki kemampuan hidup sebagai pribadi dan warga negara yang beriman, produktif, kreatif, inovatif, dan efektif, serta mampu berkontribusi pada kehidupan masyarakat. Oleh karena itu, kompetensi pedagogik seorang guru dalam melaksanakan Pembelajaran Tematik sangat penting sekali. Adapun kompetensi pedagogik guru dalam aspek pelaksanaan merupakan kemampuan dalam melaksanakan pembelajaran yang terdiri dari kegiatan awal, kegiatan inti, dan kegiatan penutup.

Pada kegiatan awal, guru melakukan kegiatan mengecek kehadiran peserta didik dan apersepsi. Kemudian pada kegiatan inti meliputi dari beberapa kegiatan yakni mengamati, menanya, mengumpulkan informasi, mengasosiasi, dan mengomunikasikan. Adapun pada kegiatan penutup, guru melakukan refleksi dan berdo'a bersama.

Pada kegiatan mengamati, guru menggunakan mengajak peserta didik untuk mengamati gambar yang ada di buku pegangan siswa. Kemudian pada 
kegiatan selanjutnya peserta didik menyimak dan mendengarkan penjelasan dari guru. Kemudian, peserta didik melakukan kegiatan pengamatan melalui kegiatan membaca. Pada kegiatan menanya, guru memberikan stimulus kepada peserta didik untuk memancing agar peserta didik mampu berfikir nalar. Pada kegiatan mengumpulkan informasi, guru memberikan kebebasan peserta didik mencari informasi dari berbagai sumber. Kemudian pada kegiatan mengasosiasi, memberikan kesempatan kepada peserta didik untuk menalar secara mandiri dan juga berkelompok. Adapun pada kegiatan mengomunikasikan, guru memberikan kebebasan kepada peserta didik untuk menyampaikan hasilnya di depan teman-temannya.

\section{Kemampuan Guru Mengevaluasi Hasil Belajar dalam Melaksanakan Pembelajaran Tematik}

Evaluasi atau penilaian hasil belajar dalam pembelajaran tematik menggunakan penilaian autentik yang terdiri dari penilaian sikap, pengetahuan dan keterampilan. Dalam hal ini pada aspek penilaian sikap menggunakan cara observasi, pada aspek pengetahuan menggunakan tes tulis dan tanya jawab, sedangkan aspek psikomotorik menggunakan praktek atau unjuk kerja.

\section{PEMBAHASAN TEMUAN}

Kemampuan Guru untuk Memahami Peserta Didik dalam Melaksanakan Pembelajaran Tematik di Madrasah Ibtidaiyah Miftahul Hidayah Tegalsari Banyuwangi Tahun Pelajaran 2018/2019

Kompetensi pedagogik dalam aspek pemahaman peserta didik meliputi kemampuan guru dalam memahami tingkat kecerdasan peserta didik, kreativitas peserta didik, kondisi fisik, pertumbuhan dan perkembangan kognitif peserta didik. 


\section{Tingkat kecerdasan}

Berdasarkan hasil observasi, wawancara, dan dokumentasi, bahwa pemahaman guru Pembelajaran Tematik dalam aspek memahami tingkat kecerdasan peserta didiknya sudah sesuai dengan indikator pemahaman peserta didik. Hal itu dibuktikan dengan cara yang dilakukan oleh guru yakni dengan melakukan pre-test berupa tes tertulis, tanya jawab dalam proses pembelajaran, dan pengamatan. Sehingga guru mampu mengetahui kecerdasan masing-masing peserta didik.

Hal ini sesuai dengan teori yang dikemukakan oeh Rifma yang mengatakan tingkat kecerdasan peserta didik berbeda-beda. Pengetahuan guru tentang tingkat kecerdasan peserta didik akan membantu guru memilih dan menetapkan perlakuan yang mungkin akan diberikan kepada peserta didik. seorang guru seharusnya memahami masing-masing peserta didik dalam aspek kecerdasan, karena hal itu dapat membantu guru sendiri dalam menemukan cara-cara efektif dalam memilih teknik atau metode pembelajaran yang sesuai dengan masing-masing peserta didik. ${ }^{11}$

\section{Kreativitas}

Berdasarkan hasil observasi, wawancara, dan dokumentasi yang telah dilaksanakan oleh peneliti bahwa pemahaman guru Pembelajaran Tematik kelas III sudah sesuai dengan indikator pemahaman peserta didik. Dalam hal ini guru memanfaatkan proses pembelajaran guna mengembangkan kreativitas peserta didik.

Hal ini sesuai dengan teori yang dikemukakan oleh Mulyasa bahwa kreativitas bisa dikembangkan dengan penciptaan proses pembelajaran yang memungkinkan peserta didik dapat mengembangkan kreativitasnya. Secara umum guru diharapkan menciptakan kondisi yang baik, yang memungkinkan setiap peserta didik dapat mengembangkan kreativitasnya, antara lain dengan teknik kerja kelompok kecil, penugasan dan mensponsori

11 Rifma, Optimalisasi Pembinaan Kompetensi Pedagogik Guru (Jakarta: Kencana, 2016), 63-64. 
pelaksanaan proyek. Anak yang kreatif belum tentu pandai, dan sebaliknya. $^{12}$

\section{Kondisi fisik}

Berdasarkan hasil observasi, wawancara, dan dokumentasi yang dilakukan oleh peneliti, bahwasannya pemahaman guru Pembelajaran Tematik kelas III mengenai kondisi fisik peserta didik sudah sesuai dengan indikator pemahaman peserta didik. Dalam hal ini guru telah memberikan sikap dan pelayanan yang berbeda dengan peserta didik yang lainnya. Hal itu bertujuan agar tidak menimbulkan peserta didik tersebut minder atau merasa berkecil hati.

Hal ini sesuai dengan teori yang dikemukakan oleh Mulyasa bahwa terhadap peserta didik yang memiliki kelainan fisik diperlukan sikap dan layanan yang berbeda dalam rangka membantu perkembangan pribadi mereka. Misalnya guru harus bersikap lebih sabar dan telaten, tetapi dilakukan secara wajar sehingga tidak menimbulkan kesan negatif. Perbedaan layanan (jika mereka bercampur dengan anak yang normal) antara lain dalam bentuk jenis media pendidikan yang digunakan, serta membantu dan mengatur posisi duduk. ${ }^{13}$

\section{Pertumbuhan Dan Perkembangan Kognitif Peserta Didik}

Berdasarkan hasil observasi, wawancara, dan dokumentasi yang dilakukan oleh peneliti, bahwasannya guru Pembelajaran Tematik kelas III mengenai pertumbuhan dan perkembangan peserta didik beranggapan bahwa masing-masing peserta didik memiliki tingkat pertumbuhan dan perkembangan yang berbeda. Hal ini menunjukkan bahwa guru mampu memahami sesuai dengan indikator pemahaman peserta didik.

Hal ini sesuai dengan teori yang diungkapkan oleh Mulyasa bahwa pertumbuhan dan perkembangan dapat diklasifikasikan atas kognitif, psikologis dan fisik. Pertumbuhan dan perkembangan berhubungan dengan

${ }^{12}$ Mulyasa, Standar Kompetensi, 85-88.

${ }^{13}$ Ibid., 89-90. 
perubahan struktur dan fungsi karakteristik manusia. Perubahan-perubahan tersebut terjadi dalam kemajuan yang mantap, dan merupakan suatu proses kematangan. Perubahan-perubahan ini tidak bersifat umum, melainkan merupakan hasil interaksi antara potensi bawaan dengan lingkungan. Baik peserta didik yang menyenangkan atau menggelisahkan, tinggi ataupun renda, sebagian besar tergantung pada interaksi antara kecenderungan bawaan dan pengaruh lingkunga. ${ }^{14}$

Dari hasil pemaparan data di atas, peneliti menyimpulkan bahwa kompetensi pedagogik guru Pembelajaran Tematik Terpadu dalam aspek pemahaman peserta didik di MI Miftahul Hidayah Tegalsari Banyuwangi yaitu sudah sesuai dengan indikator kompetensi pedagogik guru.

Hal ini seusai dengan teori yang diungkapkan oleh Sadirman bahwa pengembangan potensi peserta didik dapat diwujudkan secara optimal ketika guru memahami peserta didik serta karakteristiknya. Dalam mengelola program belajar mengajar guru perlu mengenal kemampuan anak didik. Sebab bagaimanapun juga, setiap anak didik memiliki perbedaan-perbedaan karakteristik tersendiri, termasuk kemampuannya. Dengan demikian, dalam satu kelas terdapat bermacam-macam kemampuan. Hal ini perlu dipahami guru agar dapat mengelola proses belajar mengajar dengan tepat. ${ }^{15}$

\section{Kemampuan Guru Merencanakan Pembelajaran dalam Melaksanakan Pembelajaran Tematik di Madrasah Ibtidaiyah Miftahul Hidayah Tegalsari Banyuwangi Tahun Pelajaran 2018/2019}

Pemenuhan indikator kompetensi pedagogik yang kedua yaitu perancangan pembelajaran. Keberhasilan suatu program atau kegiatan bisa dilihat dari seberapa besar persiapan yang direncanakan untuk program atau kegiatan tersebut dengan melihat kualitas perencanaan yang telah disusun.

${ }^{14}$ Mulyasa, Standar Kompetensi, 95.

15 Sadirman, Interaksi \& Motivasi Belajar Mengajar, Edisi I., Cet, XXII (Jakarta: PT Raja Grafindo Persada, 2014), 166-167. 
Dalam hal ini guru telah membuat perencanaan Pembelajaran Tematik, guru juga menyebutkan bahwa perencanaan yang dibuat meliputi RPP yang terdiri dari beberapa komponen di dalamnya. Hal ini menunjukkan bahwa guru sudah mampu merencanakan sesuai dengan indikator kompetensi pedagogik guru.

Hal ini sesuai dengan teori yang diungkapkan oleh Mulyasa bahwa Rencana Pelaksanaan Pembelajaran pada hakikatnya merupakan suatu sistem yang terdiri atas komponen-komponen yang saling berhubungan serta berinteraksi satu sama lain dan memuat langkah-langkah pelaksanaannya untuk mencapai atau membentuk kompetensi. Maka RPP dalam pembelajaran perlu untuk direncanakan sebelum pelaksanaan pembelajaran. ${ }^{16}$

\section{Kemampuan Guru dalam Melaksanakan Pembelajaran pada Pembelajaran Tematik di Madrasah Ibtidaiyah Miftahul Hidayah Tegalsari Banyuwangi Tahun Pelajaran 2018/2019}

Pelaksanaan pembelajaran yang terdapat pada kompetensi pedagogik guru secara garis besar sudah sesuai dengan indikator kompetensi pedagogik. Dalam hal ini guru sudah mampu melaksanakan indikator pada pembelajaran tematik yang terdiri dari kegiatan mengamati, menanya, mengasosiasi, dan mengkomunikasikan. Seperti yang diungkapkan oleh Abdul Majid, bahwa dalam kegiatan pembelajaran tematik Kurikulum 2013 yang identik dengan pendekatan saintifik yaitu terdiri dari kegiatan mengamati, menanya, mengasosiasi, dan mengomunikasikan. ${ }^{17}$

\section{Mengamati}

Berdasarkan hasil observasi, wawancara, dan dokumentasi yang dilakukan oleh peneliti, guru pembelajaran tematik telah melaksanakan

${ }^{16}$ Mulyasa, Standar Kompetensi, 102.

${ }^{17}$ Abdul Majid, Pembelajaran Tematik Terpadu (Bandung: PT Remaja Rosdakarya, 2014), 211. 
tahapan ini dengan melakukan pengamatan pada materi pembelajaran yang ada pada buku pegangan siswa, yaitu tentang rambu-rambu lalu lintas. Kemudian pada kegiatan selanjutnya peserta didik menyimak dan mendengarkan penjelasan dari guru. Kemudian, peserta didik melakukan kegiatan pengamatan melalui kegiatan membaca mengenai informasi arti dari rambu-rambu lalu lintas.

Sedangkan pada Pembelajaran Tematik di kelas III B guru mengajak peserta didik mengamati gambar jenis lambang-lambang pramuka. Kemudian kegiatan selanjutnya, guru mengajak peserta didik untuk mengamati gambar dengan membaca makna dari masing-masing lambang berdasarkan penjelasan yang ada di buku. Kemudian kegiatan selanjutnya mendengarkan penjelasan dari guru.

Hal ini sesuai dengan teori yang dikemukakan oleh Abdul Majid bahwa metode mengamati sangat bermanfaat bagi pemenuhan rasa ingin tahu peserta didik. Sehingga proses pembelajaran memiliki kebermaknaan yang tinggi. Dengan metode observasi peserta didik menemukan fakta bahwa ada hubungan antar obyek yang dianalisis dengan materi pembelajaran yang digunakan oleh guru. ${ }^{18}$

\section{Menanya}

Berdasarkan hasil observasi, wawancara, dan dokumentasi yang peneliti lakukan, bahwasannya guru Pembelajaran Tematik kelas III dalam hal ini guru memberikan stimulus kepada peserta didik. Sehingga peserta didik menjadi aktif.

Hal ini sesuai dengan teori yang diungkapkan oleh Abdul Majid bahwa guru harus mampu menginspirasi peserta didik untuk meningkatkan dan mengembangkan ranah sikap, keterampilan, dan pengetahuannya. Pada saat guru bertanya, pada saat itu pula dia membimbing atau memandu peserta didiknya belajar dengan baik. Ketika guru menjawab pertanyaan

${ }^{18}$ Ibid., 211. 
peserta didiknya, ketika itu pula guru mendorong peserta didik untuk menjadi penyimak dan pembelajar yang baik. ${ }^{19}$

\section{Mengumpulkan Informasi}

Berdasarkan hasil observasi, wawancara, dan dokumentasi yang peneliti lakukan, bahwasannya guru Pembelajaran Tematik kelas III dalam hal ini guru memberikan kebebasan kepada peserta didik untuk mengumpulkan informasi.

Hal ini sesuai dengan teori yang diungkapkan oleh Abdul Majid bahwa kegiatan 'mengumpulkan informasi' merupakan tindak lanjut dari bertanya. Kegiatan ini dilakukan dengan menggali dan mengumpulkan informasi dari berbagai sumber melalui berbagai cara. Untuk itu peserta didik dpat membaca yang lebih banyak, memperhatikan fenomena atau objek yang lebih teliti, atau bahkan melakukan eksperimen. ${ }^{20}$

\section{Menalar}

Berdasarkan hasil observasi, wawancara, dan dokumentasi yang peneliti lakukan, bahwasannya guru Pembelajaran Tematik kelas III dalam hal ini guru memberikan kesempatan kepada peserta didik untuk menalar secara mandiri dan juga berkelompok untuk saling berdiskusi dan bertukar informasi. Namun dalam pelaksanannya, pada kegiatan ini peserta didik belum bisa melaksanakan secara maksimal.

Hal ini sesuai dengan teori yang diungkapkan oleh Abdul Majid bahwa istilah asosiasi dalam pembelajaran merujuk pada kemampuan mengelompokkan beragam ide dan mengasosiasikan beragam peristiwa untuk kemudian memasukkannya menjadi penggalan memori. Selama mentransfer peristiwa-peristiwa khusus ke otak, pengalaman-pengalaman yang sudah tersimpan di memori otak berelasi dan berinteraksi dengan pengalaman sebelumnya yang sudah tersedia. Proses itu dikenal sebagai asosiasi atau menalar. Dari perspektif psikologi, asosiasi merujuk pada

${ }^{19}$ Ibid., 215.

${ }^{20}$ Ibid., 217. 
koneksi antara entitas konseptual atau mental sebagai hasil dari kesamaan antara pikiran atau kedekatan dalam ruang dan waktu. ${ }^{21}$

\section{Mengkomunikasikan}

Berdasarkan hasil observasi, wawancara, dan dokumentasi yang peneliti lakukan, bahwasannya guru Pembelajaran Tematik kelas III dalam hal ini guru memberikan kebebasan peserta didik untuk menyampaikan hasil proses belajarnya, kemudian guru memberikan penjelasan ulang yang tujuannya agar peserta didik mengetahui apakah jawaban mereka sudah benar atau ada yang harus diperbaiki.

Hal ini sesuai dengan teori yang diungkapkan oleh Abdul Majid bahwa pada kegiatan akhir diharapkan peserta didik dapat mengomunikasikan hasil pekerjaan yang telah disusun baik secara bersamasama dalam kelompok dan atau secara individu dari hasil kesimpulan yang telah dibuat bersama. Kegiatan mengomunikasikan ini dapat diberikan klarifikasi oleh guru agar peserta didik mengetahui secara benar apakah jawaban yang telah dikerjakan sudah benar atau ada yang harus diperbaiki. Hal ini dapat diarahkan pada kegiatan konfirmasi sebagaimana pada Standar Proses. $^{22}$

\section{Kemampuan Guru Mengevaluasi Hasil Belajar dalam Melaksanakan Pembelajaran Tematik di Madrasah Ibtidaiyah Miftahul Hidayah Tegalsari Banyuwangi Tahun Pelajaran 2018/2019}

Salah satu penekanan dalam pembelajaran tematik adalah penilaian autentik (authentic assessment). Penilaian autentik menjadi penekanan bagi guru dalam melakukan penilaian hasil belajar peserta didik. Dalam hal ini guru sudah melakukan penilaian sesuai dengan ketentuan penilaian Pembelajaran Tematik yaitu dengan menggunakan penilaian sikap, keterampilan dan pengetahuan berdasarkan proses dan hasil belajar peserta

${ }^{21}$ Ibid., 224.

${ }^{22}$ Ibid., 234. 
didik. Pada penilaian autentik ini, kompetensi pedagogik guru Pembelajaran Tematik kelas III sudah mampu melaksanakan dengan baik.

Hal ini sesuai dengan teori yang diungkapkan oleh Rusman bahwa penilaian apek sikap dilakukan melalui observasi, penilaian diri, penilaian antarteman dan jurnal. Penilaian sikap ini bukan merupakan penilaian yang terpisah dan berdiri sendiri, namun merupakan penilaian yang pelaksanaannya terintegrasi dengan penilaian pengetahuan dan keterampilan, sehingga bersifat autentik (mengacu kepada pemahaman bahwa pengembangan dan penilaian KI-1 dan KI-2 dititipkan melalui kegiatan yang didesain untuk mencapai KI-3 dan KI-4). Aspek pengetahuan dapat dinilai dengan cara tes tertulis, tes lisan, dan penugasan. Aspek keterampilan dapat dinilai dengan cara penilaian kinerja, penilaian proyek, dan penilaian portofolio. ${ }^{23}$

\section{KESIMPULAN}

Berdasarkan hasil penelitian yang telah dilakukan di Madrasah Ibtidaiyah Miftahul Hidayah Tegalsari Banyuwangi yaitu: 1) Kompetensi Pedagogik Guru Pembelajaran Tematik Terpadu Tahum Pelajaran 2018/2019 bahwa kompetensi pedagogik guru sebagai bagian dari kompetensi yang menentukan keberhasilan suatu pembelajaran, hal ini tercermin dari kemampuan guru untuk memahami peserta didik dalam melaksanakan pembelajaran tematik, guru sudah mampu memahami sesuai dengan indikator pemahaman peserta didik pada kompetensi pedagogik guru. 2) Kemampuan guru dalam merencanakan pembelajaran sudah sesuai dengan indikator perencanaan pembelajaran pada kompetensi pedagogik guru. Kemampuan guru dalam melaksanakan pembelajaran sudah sesuai dengan indikator pelaksanaan pembelajaran pada kompetensi pedagogik guru. Namun, ada satu indikator yang perlu diperbaiki dalam kegiatan inti

\footnotetext{
${ }^{23}$ Rusman, Pembelajaran Tematik, 253-255.
} 
pada pendekatan saintifik yakni pada kegiatan menalar atau mengasosiasi.

3) Kemampuan guru dalam melaksanakan evaluasi hasil belajar sudah sesuai dengan indikator pada kompetensi pedagogik guru.

\section{DAFTAR PUSTAKA}

Ahmad Izzan et al. Membangun Guru Berkarakter. Bandung: Humaniora, tt.

E. Mulyasa. Standar Kompetensi dan Sertifikasi Guru. Bandung: PT Remaja Rosdakarya, 2012.

Imanah. Wawancara, Banyuwangi 06 Februari 2019.

Observasi di Banyuwangi 06 Februari 2019.

Permendiknas. UU RI No. 14 Tahun 2005 tentang Guru dan Dosen. Jakarta: Transmedia Pustaka, 2008.

Rifma. Optimalisasi Pembinaan Kompetensi Pedagogik Guru. Jakarta: Kencana, 2016.

Rusman. Pembelajaran Tematik Terpadu Teori, Praktik dan Penilaian. Jakarta: PT Grafindo Persada, 2015.

Sadirman. Interaksi \& Motivasi Belajar Mengajar, Edisi I., Cet, XXII. Jakarta: PT Raja Grafindo Persada, 2014.

Sugiyono. Metode Penelitian Kuantitatif Kualitatif dan R\&D. Bandung: Alfabeta, 2016. 